
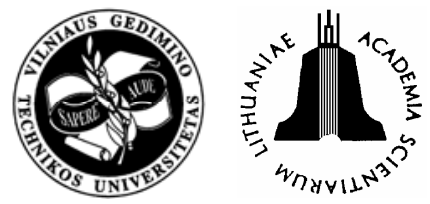

\title{
RELIABILITY AND FAILURE RESISTANCE OF THE STONE BRIDGE STRUCTURE OF CHARLES BRIDGE DURING FLOODS
}

\author{
Jiri Witzany ${ }^{1}$, Tomas Cejka ${ }^{2}$ \\ Dept of Building Structures, Czech Technical University in Prague, \\ Thakurova 7, 16629 Praha 6 - Dejvice, Czech Republic \\ E-mail: ${ }^{1}$ witzany@fsv.cvut.cz; ${ }^{2}$ cejka@fsv.cvut.cz. \\ Received 14 July 2006; accepted 26 Jan 2007
}

\begin{abstract}
The most frequent damage and collapse of some of the spans of Charles Bridge during floods occurred namely in its central part which was exposed to an intense flow of backwater and erosion of the bridge pier footing bottom, which the originally relatively shallow foundations of the piers on boxes were not able to resist for a longer time (the floods of $1432,1496,1784,1890)$. The stone vault bridge structure was damaged due to scouring of the bridge piers foundations, their successive tilting and settlement accompanied by degradation, and finally collapse of the adjoining bridge vaults. The foundation of piers on caissons and execution of caisson rings in 1892 and 1902 to 1904 in this part of the bridge, together with measures avoiding the piling up of objects in front of the bridge, enabled the bridge to withstand the impact of more than a hundred-year flood during the events of August 2002. The numerical analysis proved an extreme sensitivity of the stone vault bridge structure to the effects of changes in the footing bottom shape. Due to the changes in the footing bottom (angular rotation, subsidence, shifting), normal and shear stresses arise in the stone vault bridge structure, and exceed the load-bearing capacity of the masonry causing its disintegration. The fundamental measure to prevent the bridge vaults from failure due to the changes in the footing bottom shape is to secure reliably the bridge piers foundations. The increased rigidity of the stone bridge structure achieved by the interaction with the additionally inserted reinforcing structure and by bracing the bridge body filler does not ensure the reliability and safety of the bridge structure from floodrelated failures.
\end{abstract}

Keywords: floods, stone vault bridge structure, damage, horizontal and vertical shift, footing bottom, angular rotation, subsidence, shift, collapse of adjoining bridge vaults, bridge body filler, tensile normal and shear stresses, rigidity, breast walls, non-force effects, interaction.

\section{Introduction}

The numerical analyses of angular rotation, subsidence and shift in the footing bottom have shown extreme sensitivity of stone vault bridge structures to the effects of induced strain and the significance of these effects, which were the major cause of failure or collapse of several bridge piers and vaults in the past: Charles Bridge (Figs 1, 2) [1], bridge in Avignon etc. With a view to prevent failures of bridge structures during floods, certain structural measures were taken as early as in historical late-Romanesque and Gothic bridges. An example are recommendations [2] for the construction of overflown stone bridges where the bridge structure should exert minimum resistance to the water flow in the river even at the cost of the destruction of non-bearing parts of the bridge. This concept presumed the stripping of stone railings, also the breast walls. Historical recommendations for the construction of stone breast walls presume their simple mounting on the vault without filling in the cross-joints in the masonry, which created favourable conditions also in relation to temperature expansion of the bridge vault. With regards to the repair of an overflown bridge, the primary task was to retain the piers and bridge arches. Due to the effects of induced strain caused by the change in the shape of the footing bottom (subsidence, angular rotation, shift), the stress state occurs exceeding in some parts the strength of the stone masonry of the bridge vaults. It is the cause of opening up joints and masonry disintegration and the appearance of plastic joints, which precede the loss of stability and the collapse of the vaults. The numerical analysis of the response of the stone bridge structure to the effect of angular rotation of the bridge pier foundation manifested the appearance of the stress state (mainly tensile stresses along the entire vault cross-section) causing extensive degradation of the vault structure prior to its total destruction.

Reference [3] analyses the effect of scour as one of the major causes of the bridge failure. Scour failures tend to occur suddenly and without prior warning or a sign of distress to the structure. The nature of the failure is often a complete collapse of the entire part of a bridge. Until recently, there has been little awareness among bridge engineers of the danger of scour, compared to the effort concentrated on structural assessment.

A special problem of interest is the risk to historical bridges due to ship impact - a case of the shifting of a bridge pier in the footing bottom is mentioned in [4], which 
a) Staré Město

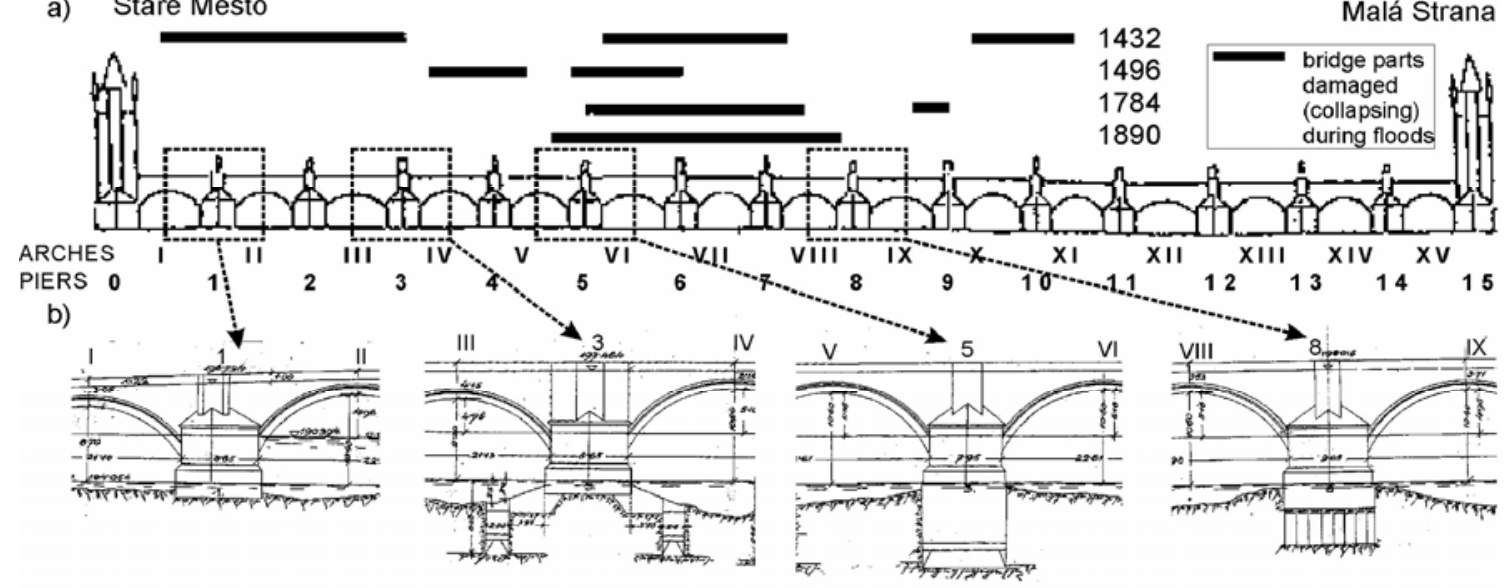

Fig 1. a) Historical development of Charles Bridge structure (according to V. Mencl, 1994). b) Foundation of bridge piers 1, 3 , 5 and 8 (documentation of 1905). Legend: - in 1902-04 shallow foundations of piers 3, 4 and 7 were secured with caisson collar beams consisting of 7 separate blocks reaching a level of Silurian slates, rehabilitation pier 8 using a collar beam of stone blocks with a sealing concrete slab of variable thickness; in 1892 foundations of bridge piers 5 and 6 were restored on caissons, in pier 8 the restored pier part, damaged in the flood of 1784, was founded on piles in 1902-04

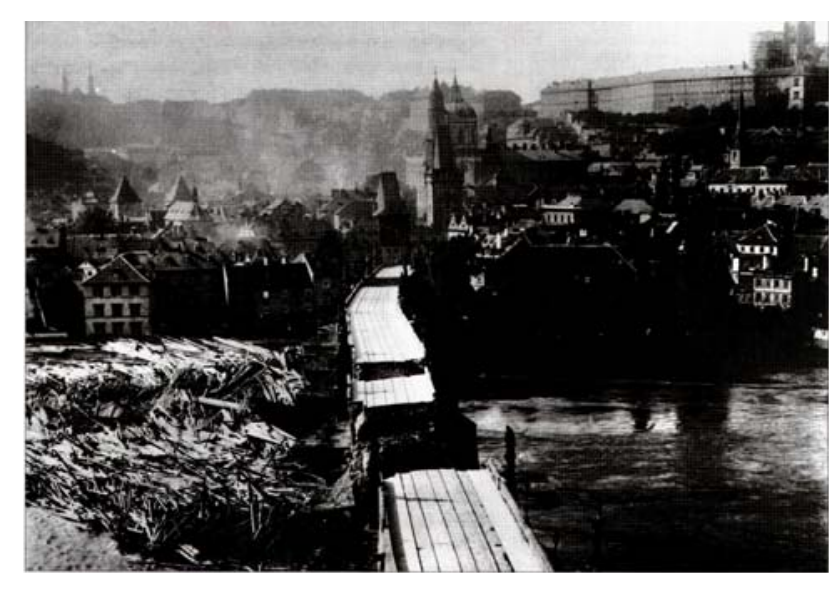

Fig 2. Collapse of 3 bridge vaults and piers of Charles Bridge during the flood of 1890

describes the investigation of two old bridges over inland waterways in Germany under a potential ship impact. The investigation is based on probabilistic calculations taking into consideration the uncertainty of a possible impact and of material parameters of historical bridges.

Reference [5] sums up the measures planned for the prepared rehabilitation and reconstruction of the mediaeval bridge in Regensburg.

Among fundamental measures taken to protect stone vault bridge structures from failure during floods are reliable, deep foundations of the bridge piers, or the rehabilitation of the existing bridge pier foundations with eg a caisson or micropile bond beam etc [6-8].

\section{Failure mechanism of stone bridge structure}

Masonry arch structures are extremely sensitive to the effect of forced deformation due to subsidence, shifting or partial turning the supporting structure. The vault degradation process is characterised by a stage when the vault gradually becomes a structurally specific construction, most often with 2 to 4 joints. This state is accompa- nied by a process when at first tension cracks typically arise and bed joints open up, and the areas around the cross sections in which the joints were formed, ie the areas where the resultant of the tension leaves the crosssection core, are locally degraded. There is also a marked growth in the tensile stresses carried by the vault crosssection leading, with eliminated tension, to a gradual, local at first, but successively total collapse of the vault. The vault degradation process is of a highly complex nature, including two significant mechanisms-changes in shape - both local and of the whole vault system, and actual degradation of the masonry due to tensile and compressive normal stresses. A total failure-the vault collapse, therefore, as a rule, results from two related parallel processes (Fig 3). It is characterised by vault buckling together with local degradation, followed by vault disintegration. Both processes are simultaneous and inseparable. The stress state in the course of its loading and degradation is explicitly described by the pressure line course at respective stages of the vault system functioning. Based on the above-mentioned premise, the basic preconditions of a reliable vault functioning involve blocking any displacement of the supports in the horizontal as well as vertical direction, and the position of the resultant of acting loads, which must lie in the vault cross-section core. In massive vaults with reserves in bearing capacity exposed mainly to symmetrical loading, tension, ie load transfer with eliminated tension $(t / 4 \geq e>$ $t / 6$ where $t$ is the vault thickness), acting on part of the resisting cross-section, may be allowed in limited vault sections, provided the increased compressive stresses do not exceed the ultimate bearing capacity limit of the masonry in compression.

The numerical analyses of the effect of the footing bottom's shape of the piers of Charles Bridge (initial response to the effect of forced deformation, angular rotation in the footing bottom, subsidence in the footing bottom) proved an extreme severity of this loading effect and the cause of frequent bridge failures during floods. 

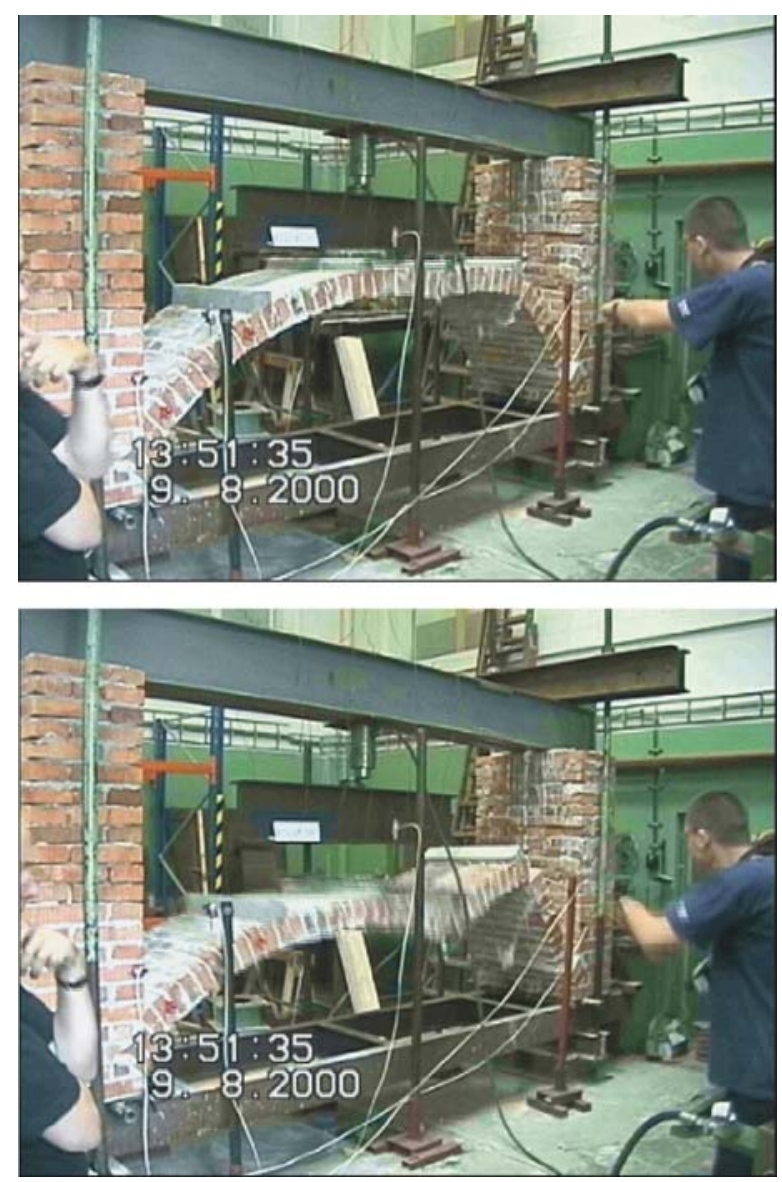

Fig 3. Vault failure under load (buckling of right vault section)

The scour and degradation of the bridge piers footing bottom, which preceded angular rotation, subsidence or shift of the bridge piers foundation, was the most common cause of the collapse of adjoining bridge vaults. The severity of this effect manifested in the vaults laid on the subsisted pier as the effect of forced deformation is given both by the exceptional sensitivity of vaults to this effect and, in case of masonry vaults, by a low tensile strength of the masonry.

The numerical analyses were made for several computational models of the bridge structure, and their results are presented in the text below for the case (Fig 4) of vaults on their own without the interaction with the breast walls, with the interaction with them and with the breast walls coupled by line joints to a reinforcement concrete slab tie of $200 \mathrm{~mm}$ thick (modification executed in some bridge spans during the repair in 1967-75).

The purpose of the numerical analyses performed is to obtain objective background material for assessing an optimum design and concept of Charles Bridge repair. The stone structure of Charles Bridge and the bridge body filler are characterised by a significant heterogeneity in terms of physical and mechanical properties of individual blocks (one bridge vault comprises over 1000 blocks differing by their physical, mechanical properties, degree of degradation by chemical and biochemical degradation processes, moisture content and dimensions) of different

\section{-A) Version vaults}
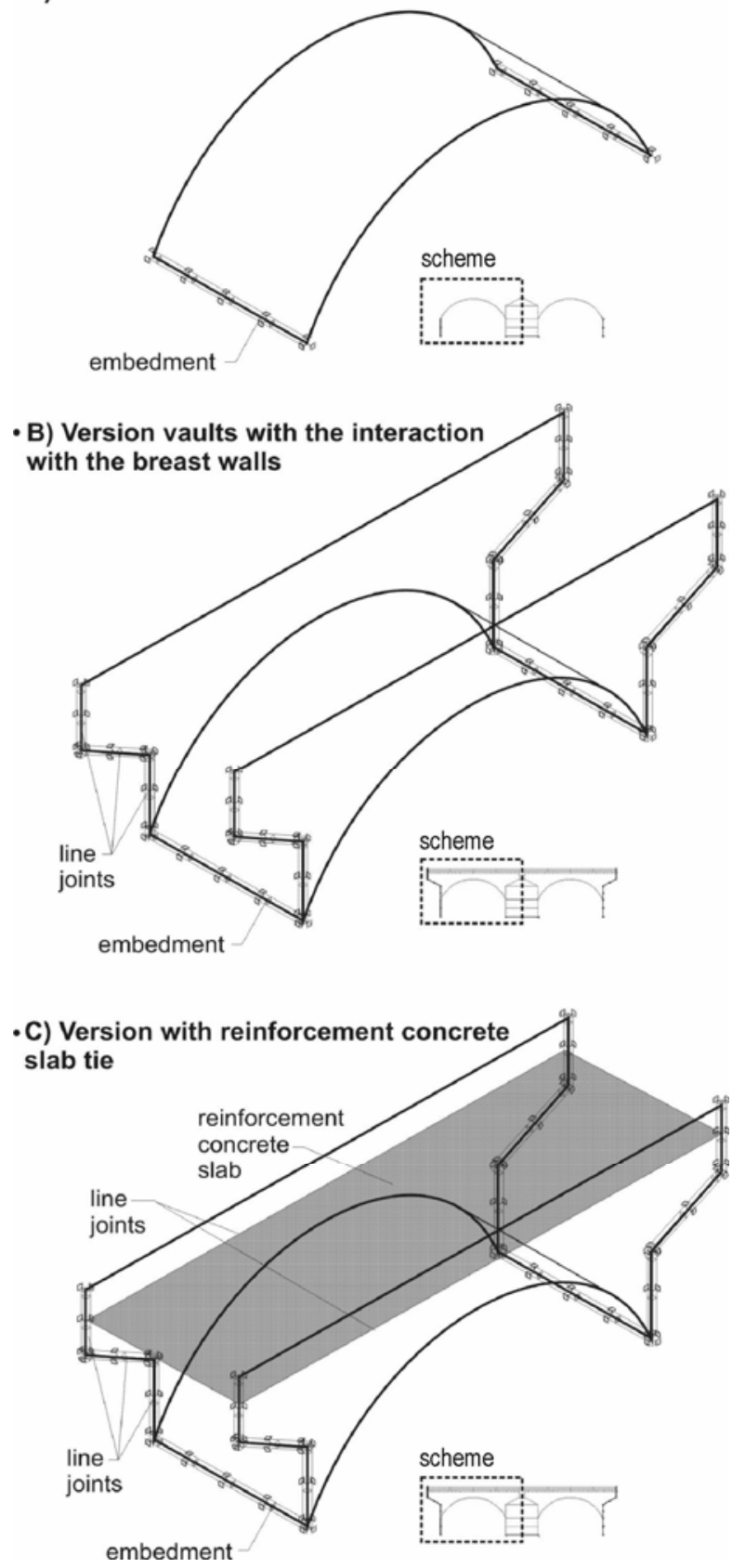

Fig 4. Scheme of investigated models of stone bridge structure

quality, thickness and composition of filling layers. This is further intensified by changing characteristics along the height of the stone blocks. With a view to these objective facts, no explicit material model of the bridge structure can be defined.

\section{Analysis of the effect of bridge pier angular rotation in footing bottom}

A theoretical computation using the finite-element method proved that the rotation of the bridge pier footing bottom at an angle $\varphi=0,06^{\circ}$ (subsidence of the bridge pier downstream edge by $10 \mathrm{~mm}$, Fig 5) is accompanied by the appearance of transverse tensile stresses $+\sigma_{y}$, with 
extreme values in the bridge vault section adjoining the subsisted edge of the bridge pier (Fig 6) and by the appearance of longitudinal tensile normal stresses $+\sigma_{x}$ (Fig 7) with extreme values in boundary areas of the bridge vault adjoining the subsisted edge of the intermediate bridge pier. In this part of the bridge vault, the tensile stress $+\sigma_{\mathrm{x}}$ acts across the whole cross-section, its numerical values considering the actual rotation (subsidence) values significantly exceed not only potential adhesion in the "mortar-stone" contact joint, but also the tensile strength of sandstone blocks. Fig 7 schematically depicts the bridge vault section, where the tensile normal stress $+\sigma_{\mathrm{x}}$ acts across the whole cross-section, and where complete disintegration and failure of the bridge vault stone masonry may be presumed.

The appearance of tensile stresses across the whole resisting cross-section of the stone vault is accompanied by disengagement of the stone blocks and their successive collapse.

Having compared the values of the normal stresses $\sigma_{\mathrm{x}}$ and $\sigma_{\mathrm{y}}$ calculated for versions $\mathrm{A}$ to $\mathrm{C}$, it is evident that the magnitude of normal stresses in adjoining bridge vaults due to an angular rotation of the bridge pier footing bottom is significantly affected by the rigidity of the resisting transverse bridge cross-section. This fact is fully in conformity with the rigidity-stress relation in a structure loaded with non-stress effects (changes in the footing bottom shape, temperature, moisture content). The magnitude of the mechanical stress state increases with the structure rigidity, or its links to the surrounding environment, which prevents a free deformation (strain) course due to non-stress effects. If the structure is not able to transfer these increased (normal and shear) stresses, its failure occurs. In this respect, the stone bridge vault structure is extremely sensitive to tensile normal and shear stresses. The growth of normal stresses in compression in the resisting cross-sections with an eliminated tension, together with a complete elimination of the parts of the structure whose cross-sections are subjected to tensile stresses along their whole extent, precedes a gradual loss in stability of the structure resulting in its total collapse.

The normal stresses $\sigma_{\mathrm{x}}$ and $\sigma_{\mathrm{y}}$ in the stone masonry of the bridge vault with the breast walls coupled to the $0,2 \mathrm{~m}$ thick concrete slab by means of a pinned joint, there is a growth in the stress state of the actual vault stone masonry of 20 to $40 \%$. The lowest values of the normal stress $\sigma_{\mathrm{x}}$ and $\sigma_{\mathrm{y}}$ in the vault stone masonry arise in version "A", ie with eliminated interaction of the bridge vault and the breast walls (Figs 7-9).

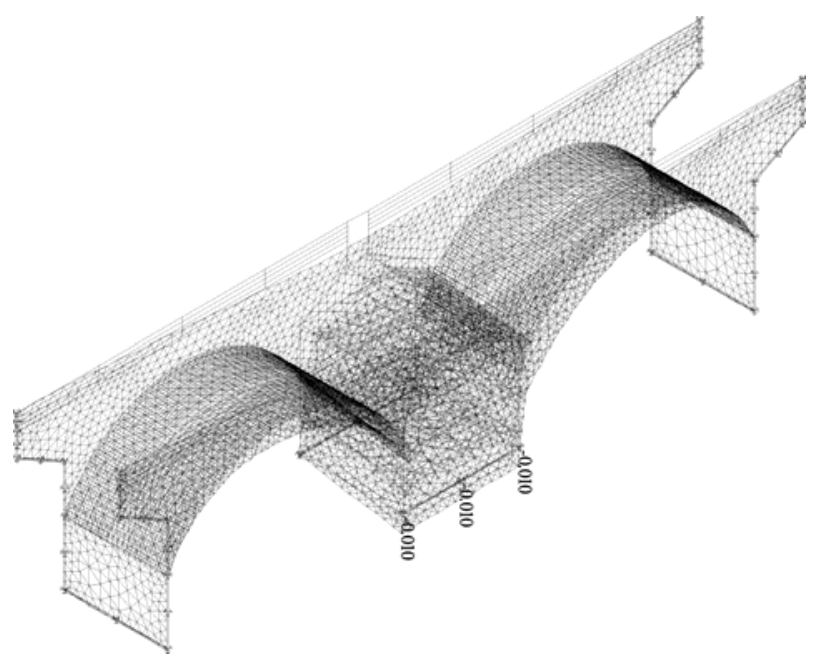

Fig 5. Diagram of bridge span deformations with angular rotation in pier footing bottom

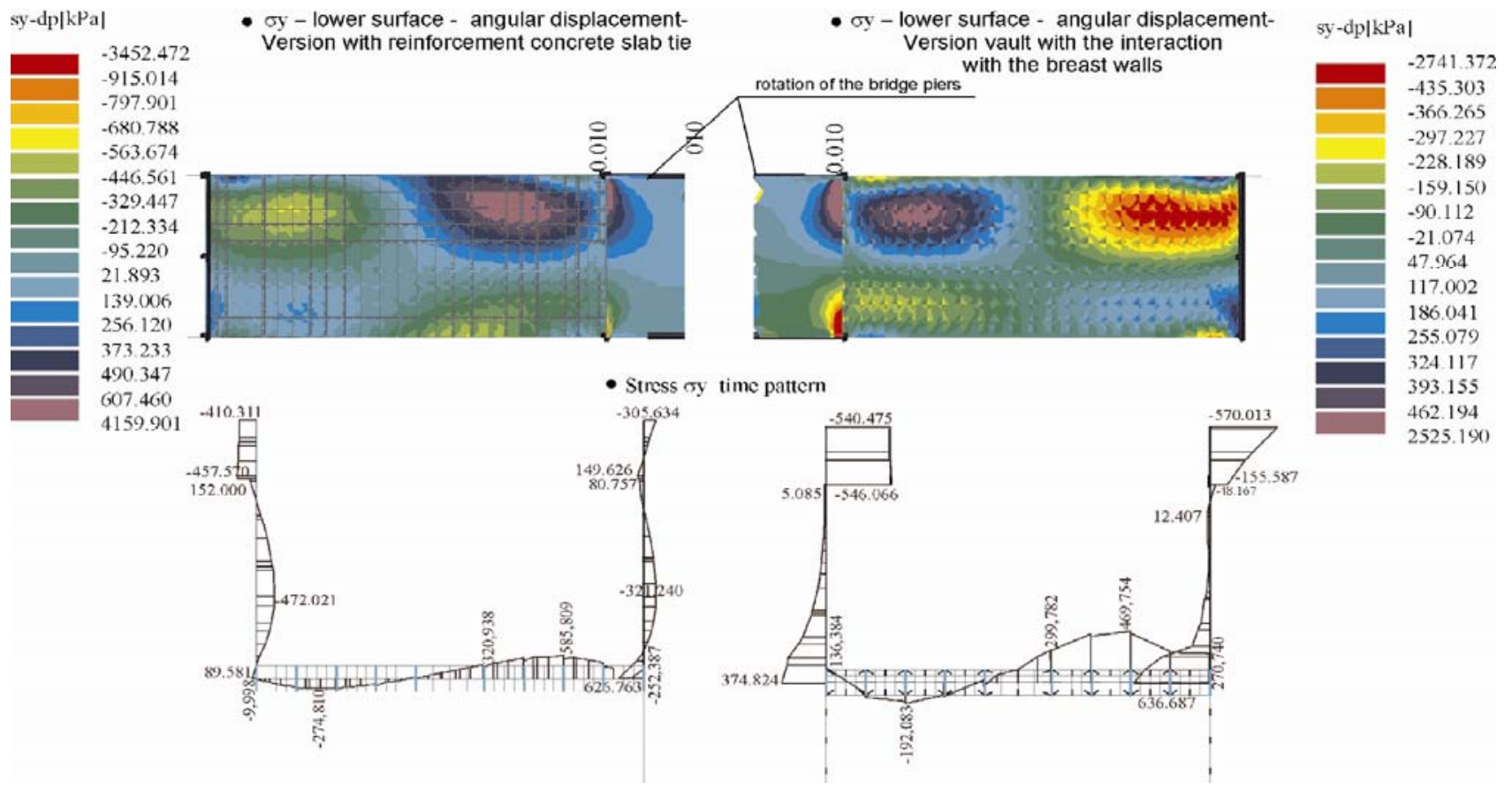

Fig 6. Transverse normal stress $\sigma_{\mathrm{y}}$ time pattern of investigated alternatives 


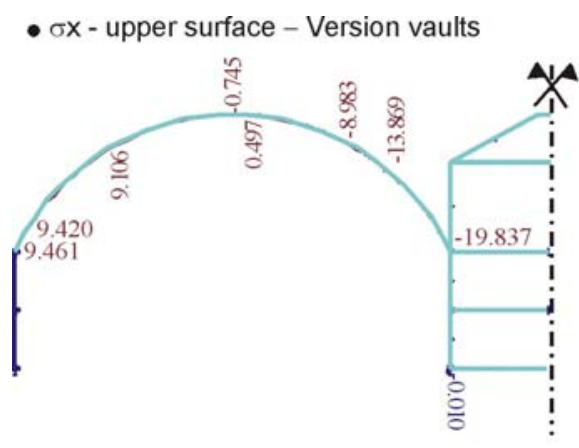

- $\sigma \mathrm{x}$ - upper surface - Version vault with the interaction with the breast walls

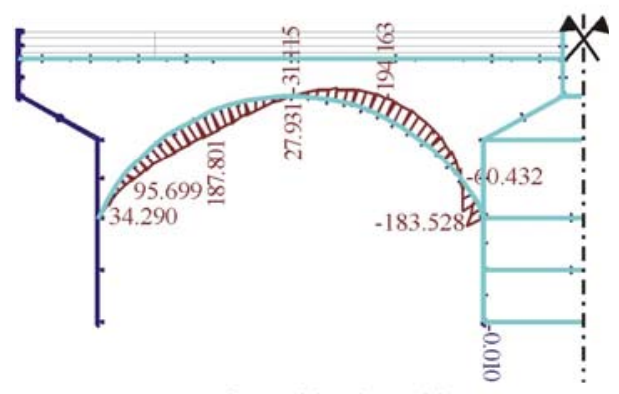

- $\sigma \mathrm{x}$ - upper surface - Version with reinforcement concrete slab tie

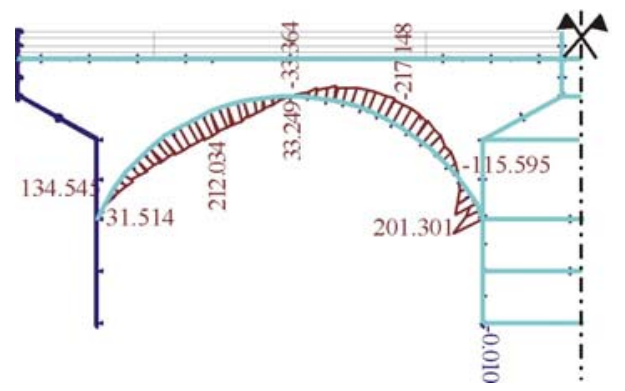

Fig 7. Comparison of normal stress $\sigma_{\mathrm{x}}$ values in a characteristic cross-section of stone bridge structure

In case of the bridge vault interacting with the breast walls coupled by a pinned joint with the reinforcement concrete slab tie, as compared to the case when the rotation effect in the footing bottom is resisted only by the bridge vaults, the normal stresses $\sigma_{\mathrm{x}}$ and $\sigma_{\mathrm{y}}$ in the vault stone masonry reach values of several times higher.

The results of the numerical analysis may be summed up as follows:

- A theoretical analysis of the first response of the bridge vaults to the effect of angular rotation of the bridge pier footing bottom (at an angle $\varphi=0,06^{\circ}-$ subsidence of the bridge pier edge by $10 \mathrm{~mm}$ ) proved the appearance of tensile normal stresses $+\sigma$ $\left(+\sigma_{x},+\sigma_{y},+\sigma_{1}\right)$ with extreme values namely in the bridge vault sections adjoining the subsisted and the diagonally opposite edge of the bridge pier. These stresses exceed the stone masonry tensile strength, both in joints and in stone blocks. The bridge vaults sections showing tensile stresses $\left(+\sigma_{x},+\sigma_{y},+\sigma_{1}\right)$ across the whole vault cross-section are the areas of initial disintegration and failure of the bridge vatult stone masonry accompanying the subsidence of the bridge pier edge due to its footing scour [1]. Due to
- $\sigma y$ - lower surface - Version vaults

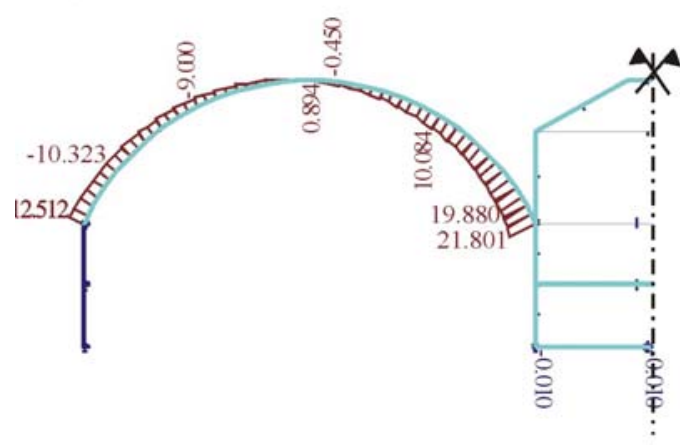

- $\sigma \mathrm{y}$ - lower surface - Version vault with the interaction with the breast walls

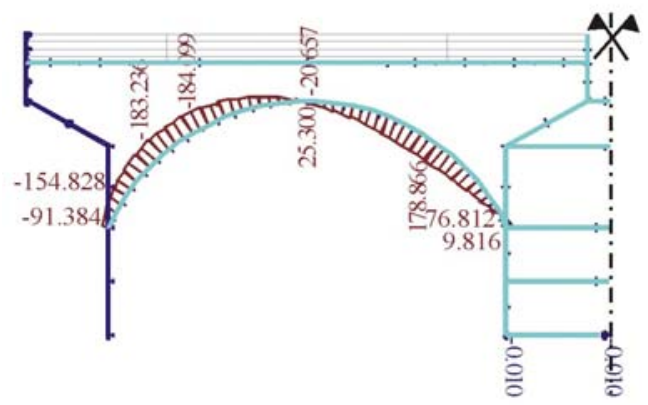

- $\sigma y$ - lower surface - Version with reinforcement concrete slab tie

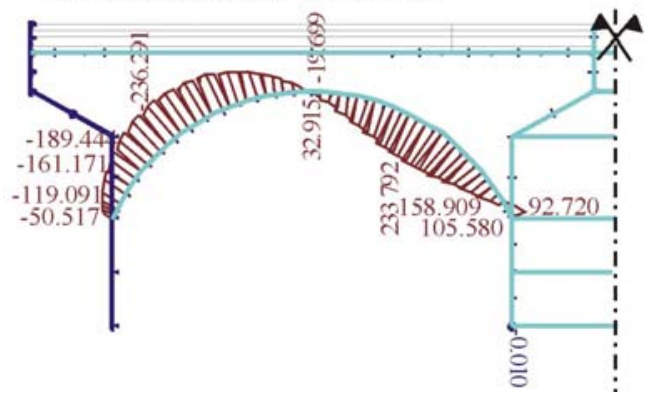

Fig 8. Comparison of normal stress $\sigma_{\mathrm{y}}$ values in a characteristic cross section of stone bridge structure

an exceptionally low ductility of the masonry, plus a relatively large section of the bridge vault developing tensile stresses along their whole cross-section, or exposed to extreme compressive stresses, the whole process of the bridge vault collapse is accelerated.

- This analysis has manifested that the reinforcement concrete slab ties with pinned joint coupling to the breast walls whose effect results is a total growth in the load acting on the vault structure due to a change in the footing bottom shape will accelerate the process of disintegration and successive collapse of adjoining bridge spans. In the subsequent stages preceding the collapse of the bridge structure, significant stress redistribution occurs characterised by the failure of the cross-sections loaded with tension and the cross-sections in which the compressive strength of the stone masonry has been exceeded.

- Due to the above-mentioned facts we may state that the reinforcement concrete slab tie coupling the breast walls (carried out as part of the bridge repair 

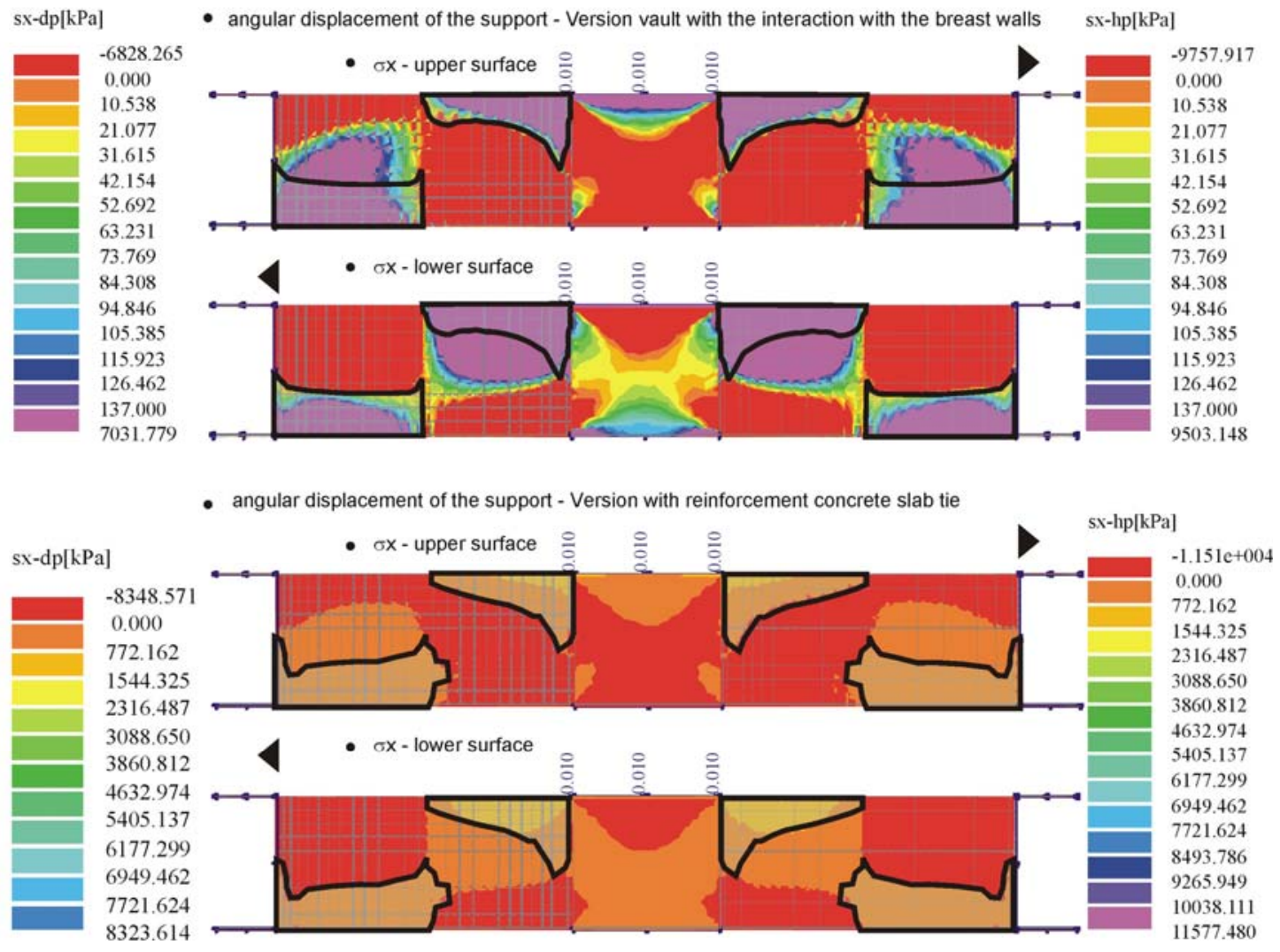

Fig 9. Areas of tensile normal stress $+\sigma_{\mathrm{x}}$ occurrence acting along whole vault cross-section (areas of tensile stresses acting along whole cross-section highlighted in bold) first iteration - response of structure

in 1966-75) reduces the resistance and safety of the stone structure of Charles Bridge because of a potential scour of the bridge piers foundations exposed to increased water flows mainly during floods.

\section{Numerical analysis and modelling the effect of bridge piers subsidence or shift in the footing bottom on the failure of the stone bridge structure}

The subject of the analysis of the first response of the bridge vaults adjoining the pier in whose vicinity subsidence (selected subsidence value used $\Delta_{\mathrm{z}}=10 \mathrm{~mm}$ ) or shift in the footing bottom occurs due to the effect of floodwater pressure and accumulated objects (selected value used $\Delta_{\mathrm{y}}=10 \mathrm{~mm}$ ) was to compare the extreme values of normal stresses and their distribution across the vault surface as calculated for individual versions of computational models [9].

The results of the numerical analysis may be summed up as follows:

- In case of subsidence or shift in the footing bottom, at theoretically considered, relatively small values of forced deformations $\left(\Delta_{\mathrm{z}, \mathrm{y})}=10 \mathrm{~mm}\right)$, normal stresses $\sigma_{\mathrm{x}}$ and $\sigma_{\mathrm{y}}$ arise in some vault cross-sections, which exceed the tensile (or even compressive) strength of the stone masonry of the bridge vaults and which precede, together with masonry disintegration in the areas of tensile stresses across the whole vault cross-section, the first stage of the bridge vaults failure.
- In case of the bridge pier subsidence (Figs 10, 11), due to the effect of the vault interaction with the breast walls, there is an increase and a considerable change in the transverse normal stresses $\sigma_{\mathrm{y}}$. When the breast walls are coupled by means of a reinforcement concrete slab tie, there is an additional growth in transverse normal stresses in the vault masonry by 30 to $60 \%$, as compared to versions with the breast walls; longitudinal normal stresses $\sigma_{\mathrm{x}}$ in the bridge vault version, ie vaults on their own, as compared to the version of bridge vaults interacting with the breast walls and the version where the bridge vaults interact with the breast walls coupled by means of a reinforcement concrete slab tie, ie including the interaction with the breast walls, reach values up to several times higher. The breast walls coupling by means of the reinforcement concrete slab tie negatively affects the response of the stone bridge structure to loading effects. Due to the interaction of the breast walls with the reinforcement concrete slab tie, there is a total increase in the rigidity of the bridge structure and a related additional increase in longitudinal normal stresses $\sigma_{\mathrm{x}}$ (by 30 $40 \%$ ), as compared to versions of bridge vaults interacting with the breast walls.

In case of the pier shift in the footing bottom (Figs 12, 13) due to the bridge vault interaction with the breast walls or the breast walls coupled by the reinforcement concrete slab tie, there is a significant fall in both transverse and longitudinal normal stresses $\sigma_{y}$ and $\sigma_{x}$ (by ca $50 \%$ ). High 


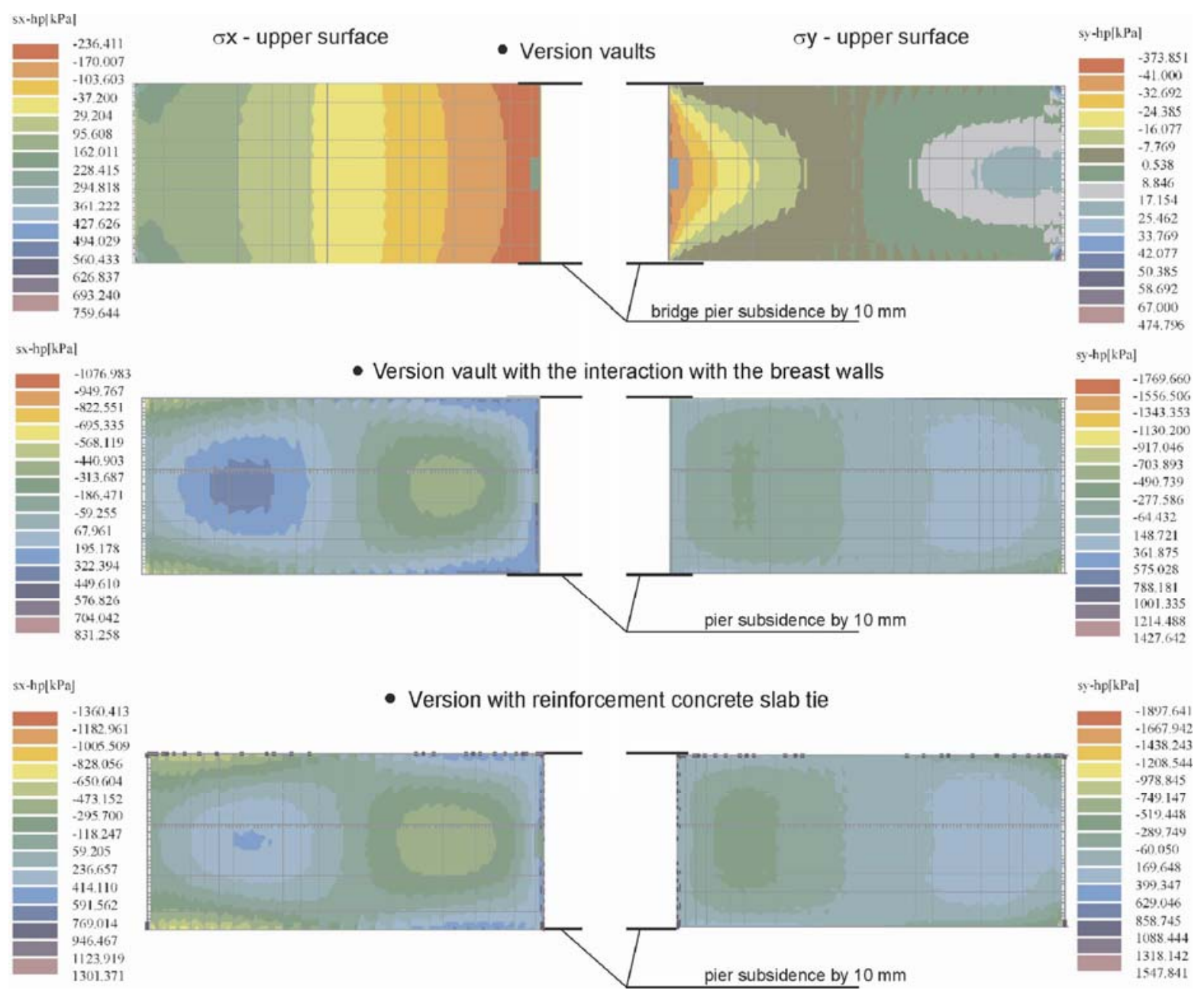

Fig 10. Field of normal stresses $\sigma_{\mathrm{x}}$ (longitudinal) and $\sigma_{\mathrm{y}}$ (transverse) in bridge vault at pier subsidence by $10 \mathrm{~mm}$
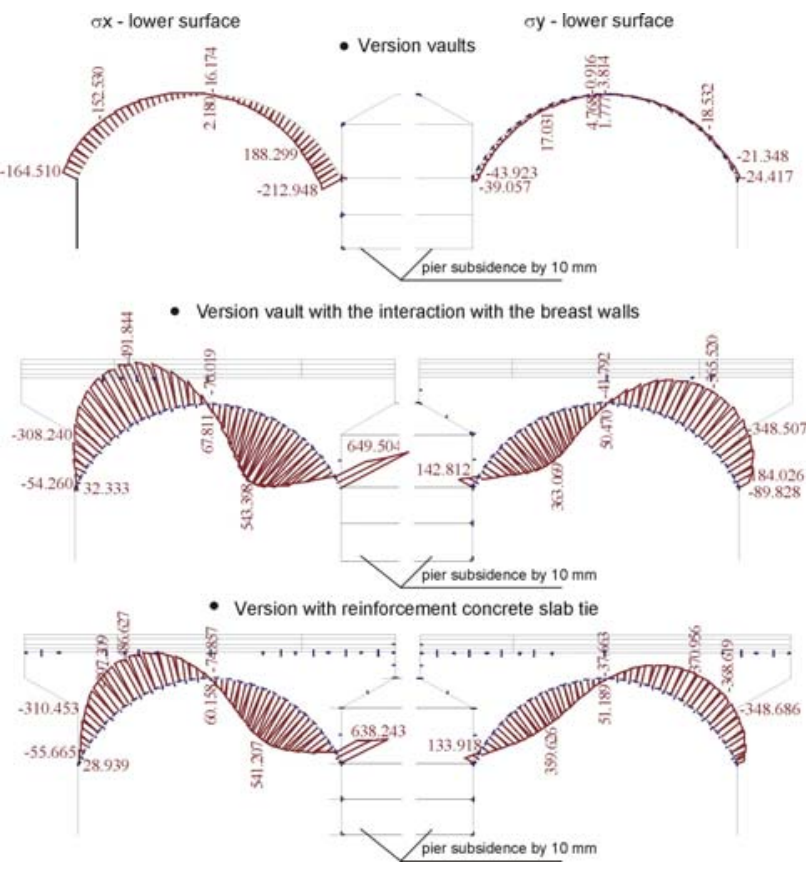

Fig 11. Scheme of course of normal stresses $\sigma_{x}$ and $\sigma_{y}$ in longitudinal vault axis at pier subsidence by $10 \mathrm{~mm}$ values of longitudinal normal stresses $\sigma_{\mathrm{x}}$ arise in the bridge vault reaching, as compared to the values of transverse normal stresses $\sigma_{y}$, values more than twice. The differences in the magnitude of normal stresses $\sigma_{y}$ in individual cases with the breast walls are within a range of ca $\pm 10 \%$. Considerable shifting forces arise in the footing small effect of the reinforcement concrete slab tie in terms of the "resistance" of the bridge structure to the bridge pier shift in the footing bottom is evident. The decisive finding is the interaction of the bridge vault with the breast walls - a critical point being the bed joint between the vault and the breast wall. Increased horizontal rigidity of the breast walls in case of their coupling by the reinforcement concrete slab tie will "accelerate" the bed joint failure and the successive process of the vault failure (Fig 14).

The magnitude of the stress in all its component parts due to the effect of non-stress effects is significantly affected by the structure rigidity. The magnitude of the mechanical stress grows with the structure rigidity, which "prevents" a free deformation course due to a non-stress effect. A growth in eg tensile normal stresses in the stone masonry of the bridge vaults is the cause of cracking and masonry degradation. Any potential change in the rigidity 


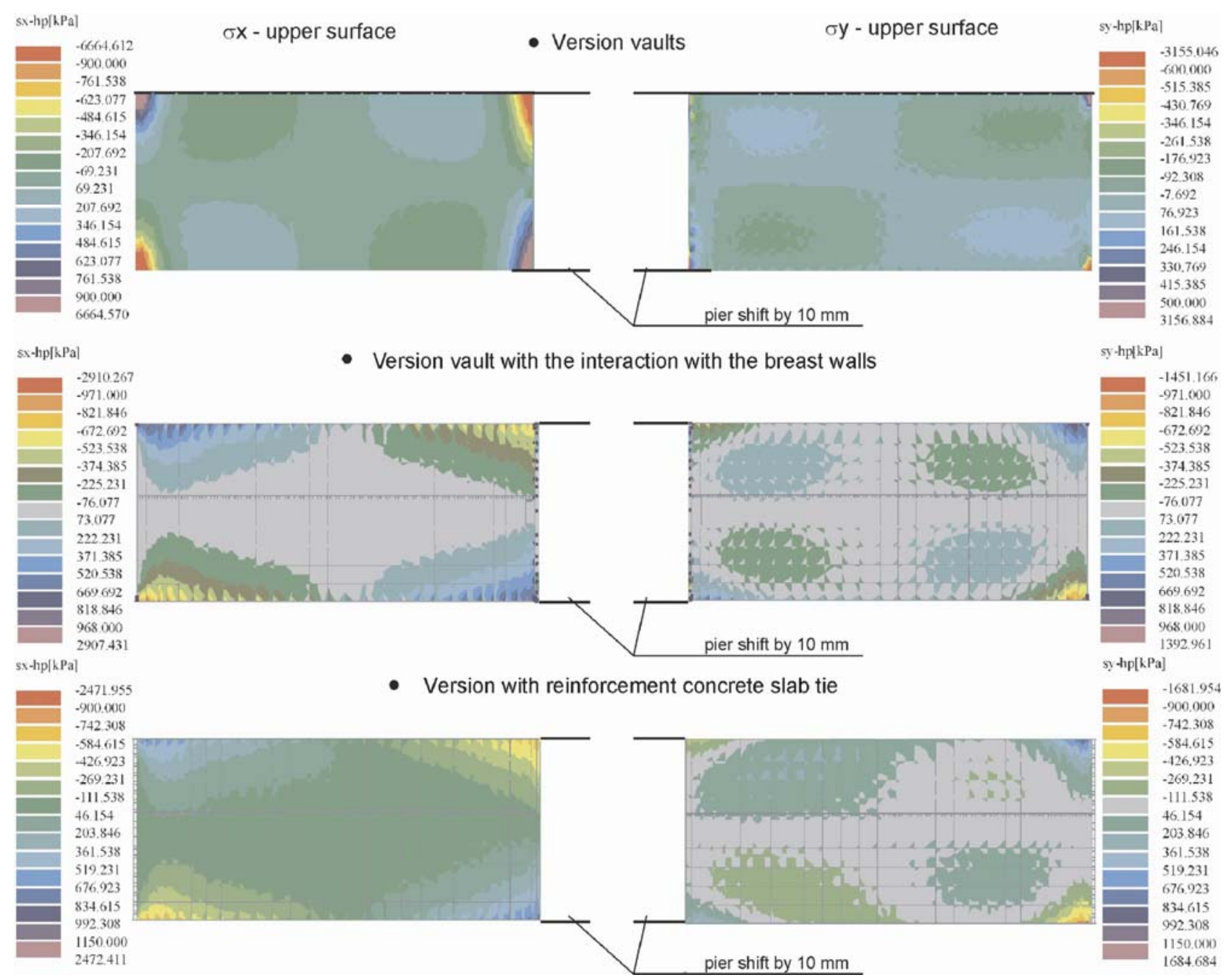

Fig 12. Field of normal stresses $\sigma_{\mathrm{x}}$ (longitudinal) and $\sigma_{y}$ (transverse) in bridge vault at bridge pier shift by $10 \mathrm{~mm}$

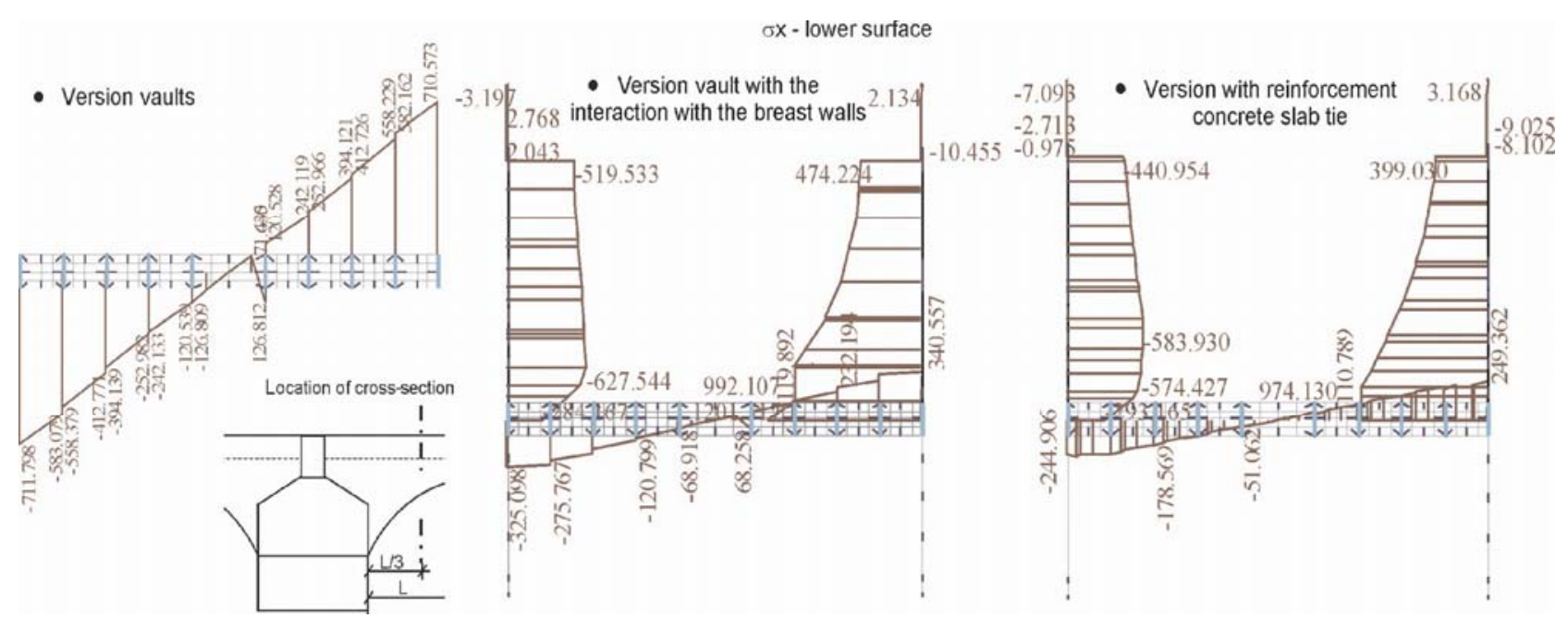

Fig 13. Scheme of course of normal stresses $\sigma_{\mathrm{x}}$ (longitudinal) on lower vault surface (in $1 / 3$ of vault span) at bridge pier shift by $10 \mathrm{~mm}$ 
of the bridge resulting from reconstruction works must be confirmed mainly by the relation to the effects of nonforce and cyclic effects such as temperature, moisture content and a change in the shape of the footing bottom. Optimisation of this problem consists in finding such rigidity that will prevent the appearance of mechanical stress causing the failure of the structure and, at the same time, prevent excessive deformations whose residual component would - by gradual increments in individual loading cycles - result in the disintegration of the bridge structure.

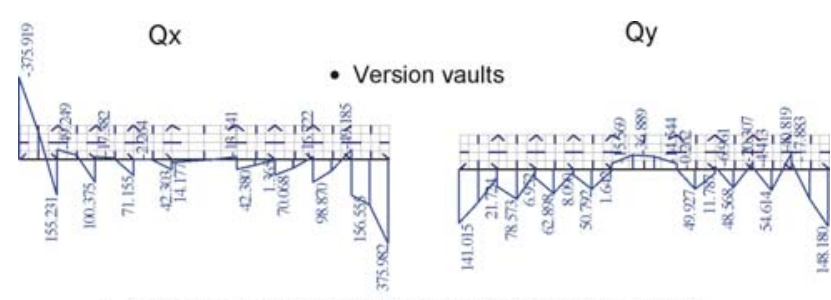

- Version vault with the interaction with the breast walls

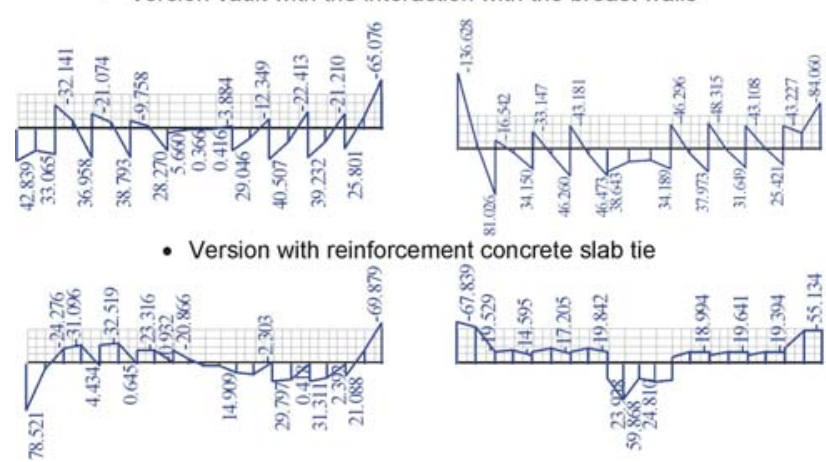

Fig 14. Course of shifting forces $\mathrm{Q}_{\mathrm{x}}, \mathrm{Q}_{\mathrm{y}}$ at vault toe adjoining bridge pier in which shift in footing bottom occurred

\section{Conclusions}

- The analysis of the first response of the bridge vaults to the effect of forced deformation - angular rotation, subsidence, shift of the bridge pier in the footing bottom - has proved the extreme gravity of this effect, which, in case of insufficient securing of the bridge piers footings, represents a real threat to Charles Bridge.

- A high risk and probability of the bridge vaults collapse when changing the shape of the footing bottom of the bridge piers requires securing the bridge piers to resist this effect. The fundamental measure is protection of the bottom of the piers, with footings at the original shallow level, from erosion effects of water flow, namely, during a higher water discharge.

- The numerical analyses performed prove that due to the prevailing negative effect of eg the breast walls coupling by means of the reinforced concrete slab tie, reliable securing the bridge structure against non-force effects and impacts of forced deformation cannot be achieved by simply increasing the rigidity and by the interaction of embedded constructions (inserted into the bridge body) with the stone bridge structure. The theoretical analyses and long-term monitoring of the stone bridge structure manifested the predominantly negative effects of increased rigidity of the bridge body filling layers and the breast walls bracing with the reinforced concrete slab tie, which resulted in creating different boundary conditions for the transfer of loads and structural action of the vault bridge structure. The bridge vaults, originally designed for transferring loads mostly via pressures acting in the vault section core, become, due to the interaction, part of a more complex structural system with a different mechanism of their action and loading. The solution to this problem consists in finding an optimum rigidity of the bridge structure in terms of the mutual interaction and rigidity of the vault structure, the breast walls and the bridge body filler under which the mechanical stress states will not exceed the load-bearing capacity of the stone masonry (mainly in tension) eliminating, at the same time, excessive deformations so that the residual component of each coming deformation is at least by one to two orders lower than the total deformation of the bridge structure, thus preventing progressive and gradual disintegration of the stone structure.

- The breast walls coupling by means of the reinforcement concrete slab tie, the bracing of the bridge body filler and increasing the mutual interaction of the stone bridge structure with the bridge filler is an undesirable way of increasing the rigidity, and thus also the stress state of the bridge structure exposed to permanently present and cyclic mechanical stress states caused by changes in temperature and moisture content, as well as to processes which gradually degrade its mechanical resistance reducing the longevity of Charles Bridge $[10,11]$.

\section{Acknowledgement}

This article was written with support of the research project VZ1 MSM 6840770001 "Reliability, optimisation and durability of building materials and structures".

\section{References}

1. WITZANY, J. et al. Chemical and biochemical degradation of Charles Bridge, analysis of resistance and safety of the stone bridge structure in floods, exploration of footing masonry and pier footings. Stavebni obzor (Civil Engineering Journal), 2003, 6, p. 161-180 (in Czech).

2. KOLÁř, J.; KLOKNER, F. Stone and brickwork bridges. Technical guide 11. Prague, Czech Republic, 1951 (in Czech).

3. DE FALCO, F.; MELE, R. The monitoring of bridges for scour by sonar and sedimetri. NDT \& E International, 2002, 35(2), p. 117-123.

4. PROSKE, D.; CURBACH, M. Risk to historical bridges due to ship impact on German inland waterways. Reliability Engineering \& System Safety, 2005, 90(2-3), p. 261-270. 
5. SWACZYNA, A. Steinerne Brücke in Regensburg Erhaltung eines Kulturdenkmals von Europäischer Bedeutung. Fachzeitschrift Natursteinsanierung Stuttgart 2006. Neue Natursteinrestaurierungsergebnisse und messtechnische Erfassungen, 17 März 2006, Stuttgart. Fraunhofer IRB Verlag, 2006, p. 95-111.

6. WITZANY, J. et al. Comprehensive assessment of a theoretical and experimental investigation of Charles Bridge 1994 to 2004 - Part 1. Stavebni obzor (Civil Engineering Journal), 2005, 3, p. 65-83.

7. WITZANY, J. et al. Comprehensive assessment of a theoretical and experimental investigation of Charles Bridge 1994 to 2004 - Part 2. Stavebni obzor (Civil Engineering Journal), 2005, 4, p. 97-105 (in Czech).

8. WITZANY, J. et al. Assessment of current structural and maintenance condition of Charles Bridge. Stavebni obzor (Civil Engineering Journal), 2002, 8, p. 225-249 (in Czech).
9. WITZANY, J.; CEJKA, T. Analyses of resistance and safety of the stone bridge structure in floods. In Proc of the 2nd International Conference on Structural Engineering, Mechanics and Computation (SEMC 2004), Cape Town, South Africa, 5-7 July 2004. A. A. Balkema, 2004, p. 15-23.

10. WITZANY, J.; JÄGER, W. Die Karlsbrücke in Prag, Bewertung des bautechnischen Zustandes. Mauerwerk, 2005, 9(3), p. 108-119.

11. WITZANY, J. Construction conditions and reconstruction of Charles Bridge. Inzenyrska komora (CKAIT Journal), 1997, Special Issue, p. 8-19 (in Czech).

\section{KAROLIO TILTO MŪRINIŲ KONSTRUKCIJŲ PATIKIMUMAS IR ATSPARUMAS PER POTVYNIUS}

\section{J. Witzany, T. Cejka}

\section{Santrauka}

Potvynių metu Karolio (angl. Charles) tilte Čekijoje didžiausios pažaidos ir suirimai atsirado centrinèje dalyje, kuri buvo paveikta intensyvia vandens tèkme. Potvynių metu taip pat vyko pagrindo po tilto tarpine atrama erozija, dèl kurios atramos pamato tolesné eksploatacija buvo negalima (1432, 1496, 1784, 1890 metų potvyniai). Arkiné mūriné tilto konstrukcija buvo pažeista dèl pagrindų po atramų pamatais išplovimo. Dẻl to atsirado pamato posvyris bei nuosedis, o tai, sukèlè tilto mūrinių skliautu pažaidas, o vèliau - ir suirimą. Šioje tilto dalyje $1892 \mathrm{~m}$. ir 1902-1904 metais irengti kesoniniai pamatai sustiprino tilto konstrukcija, kuri atlaikè $2002 \mathrm{~m}$. rugpjūti vykusi potvyni. Atliktas skaitinis eksperimentas parodè, kad arkinè mūrinio tilto konstrukcija yra labai jautri pagrindo deformacijoms. Dèl pagrindo deformacijų (pasisukimo, nuosėdžio, pasislinkimo) padideja normaliniai ir tangentiniai įtempiai arkų konstrukcijose. Kritiniais atvejais šie įtempiai viršija mūro stiprumo ribą, o tai sukelia mūro suirimą. Klasikinè mūrinių arkinių tiltų apsaugos nuo suirimo dèl pamato deformaciju priemonè, yra patikimas pamatu po tarpinemis tilto atramomis stiprinimas. Bendrasis tilto standumas buvo padidintas irengus papildomą laikančiają gelžbetoninę konstrukciją bei sutvirtinus anstato užpildymą, tačiau tai neužtikrino tilto konstrukcijų patikimumo ir saugos potvynių metu.

Reikšminiai žodžiai: potvyniai, arkinis mūrinis tiltas, pažaida, horizontalusis ir vertikalusis poslinkis, pamato pagrindas, pasisukimas, nuosėdis, poslinkis, tilto skliautų suirimas, antstato užpildymas, normaliniai ir tangentiniai tempimo įtempiai, standumas, antstatas, klimatiniai poveikiai, sąveika.

Prof Ing Jiří WITZANY. Dr Sc, Rector Emeritus, Head of Dept of Building Structures, chief researcher of the research plan "Reliability, optimisation and durability of building materials and structures" and grant project "Reliability analysis of characteristics of building materials and structures with regard to their time-related changes and time-variable effects". He devotes himself to structural problems of designing building structures, has carried out extensive theoretic and experimental research on prefabricated structures, reconstruction and rehabilitation designs of concrete and masonry buildings, degradation processes, durability and reliability of buildings. He has elaborated the reconstruction concept of Charles Bridge.

Ing Tomáš ČEJKA, PhD. Assistant Lecturer at the Dept of Bulding Constructions, Faculty of Civil Engineering, Czech Technical University in Prague, Czech Republic. His research interests include structural analysis, mainly of masonry and precast conrete structures, reconstructions and renovations of buildings etc. 